Електронне наукове фахове видання "Ефективна економіка" включено до переліку наукових фахових видань України з питань економіки

(Наказ Міністерства освіти і науки України від 11.07.2019 № 975) www. economy.nayka.com. ua | № 10, 2019 | 31.10.2019 p.

DOI: $\underline{10.32702 / 2307-2105-2019.10 .17}$

UDC 332

I. V. Zablodska

Doctor of Economic Sciences, Professor,

Director of the Luhansk Branch of the Institute of Economic and

Legal Research of the NAS of Ukraine, Kyiv, Ukraine

ORCID: 0000-0002-1410-6194

V. O. Kasyanova

Candidate of Economic Sciences, Associate Professor at the Department of Economics and Entrepreneurship, Institute of Chemical Technologies of

Dahl East Ukrainian National University, Rubizhne, Ukraine

ORCID: 0000-0002-0857-7934

\title{
ECONOMIC AND FINANCIAL ELEMENTS, FEATURES AND FUNCTIONS REGIONAL REAL ESTATE MARKET
}

\author{
I. В. Заблодська, \\ д. е. н, професорка, директорка Луганської філії Інституту економіко-правових досліджень \\ НАН України, м. Київ, Украӥна \\ В. О. Касьянова, \\ к. е. н. дочент кафедри економіки та підприємництва Інституту хімічних технологій \\ Східноукраӥнського національного університету ім. В. Даля, м. Рубіжне, Украӥна
}

\section{ЕКОНОМІЧНІ ТА ФІНАНСОВІ ЕЛЕМЕНТИ, ОСОБЛИВОСТІ І ФУНКЦІї РЕГІОНАЛЬНОГО РИНКУ НЕРУХОМОСТІ}

The development of the Ukrainian real estate market correlates with the general trends of macroeconomic processes in the country and its regions. The article defines the economic and financial elements, features and functions of the regional real estate market of Ukraine. It is found that the regional real estate market is a set of organizational and economic relations, a means of land redistribution, buildings, structures and other property between owners and users economic methods based on competitive demand and supply in the territory of region (area). The basis of the regional real estate market is existing land, buildings and structures for various purposes, as well as money or financial capital. According to the research results, the regional real estate market in Ukraine as a selfregulatory system consists of seven basic economic and financial elements, namely: demand, supply, price, management, marketing, infrastructure and business procedures. The basis of the regional real estate market is the existing land plots of region and the newly created ones, reconstructed and expanded enterprises, buildings and constructions of different purpose, as well as money or financial capital. The features of the regional real estate market are follow: market localization, real estate transactions are exclusive and confidential, demand is determined by their location, low elasticity of supply, high degree of market state regulation by legislative norms, real estate market serves as an object of investment, there was a small variability in demand by regions, districts and districts. The regional real estate market has a great impact on all aspects of people's lives and activities, performing a number of general and special functions. The functions of the regional real estate market include setting of equilibrium prices, 
information, regulation, commercial, sanitation, redistribution, intermediary, stimulating, investment, social. Further research should be conducted in the context of identifying regional features of the real estate market.

Розвиток украӥнського ринку нерухомості корелює з загальними тенденціями макроекономічних прочесів в країні та ї̈ регіонах. У статті визначено економічні та фінансові елементи, особливості і функиії регіонального ринку нерухомості України. З'ясовано, щзо регіональний ринок нерухомості це сукупність організаційно-економічних відносин, засіб перерозподілу земельних ділянок, будівель, споруд та іншого майна між власниками $і$ користувачами економічними методами на основі конкурентного попиту і пропозиції на території регіону (області). Основу регіонального ринку нерухомості складають існуючі земельні ділянки, будівлі і споруди різного иільового призначення, а також гроші чи фінансовий капітал. За результатами досліджень визначено, що регіональний ринок нерухомості в Україні як саморегулююча система складається з семи основних економічних та фінансових елементів, а саме: попит, пропозиція, ціна, менеджмент, маркетинг, інфраструктура $і$ ділові процедури. Основу регіонального ринку нерухомості складають існуючі земельні ділянки регіону та новостворювані, підприємства які реконструюються та розширюються, будівлі і споруди різного иілььового призначення, а також гроші чи фінансовий капітал. Встановлено особливості регіонального ринку нерухомості, які полягають у наступному: локалізачія ринку, операції з нерухомістю носять ексклюзивний $i$ конфіденційний характер, попит визначається за місцем їх розташування, низька еластичність пропозииї, високий ступінь державного регулювання ринку законодавчими нормами, ринок нерухомості служить об'єктом інвестицій, мала змінність попиту по регіонах, районах $i$ мікрорайонах. Регіональний ринок нерухомості має великий вплив на всі сторони життя $i$ діяльності людей, виконуючи ряд загальних і спеціальних функиій. До функцій регіонального ринку нерухомості віднесено: встановлення рівноважних иін, інформаційна, регулювання, комериійна, санірування, перерозподільна, посередницька, стимулююча, інвестиційна, соиіальна. Подальші дослідження мають бути проведені в контексті визначення регіональних особливостей розвитку ринку нерухомості.

Keywords: elements, functions, features, real estate market, region.

Ключові слова: елементи, функції, особливості, ринок нерухомості, регіон.

Topicality. The European integration vector of Ukraine's development implies the changes not only in the economic space but also in other spheres of societies life, namely in real estate. Because the real estate market depends on economic processes just like other commodity, labor or financial markets. The development of the real estate market testifies to the general trends of macroeconomic processes in the country and its regions. Its trends in the development of the regional real estate markets that allow us to identify the problems or victories in the socio-economic development of the state's economy. Therefore, the definition and research of elements, functions and features of the regional real estate market are timely and relevant due to the dynamic changes taking place in the regions of Ukraine.

Analysis of recent research. The scientific and educational literature contains a number of publications on the functioning of the regional real estate market, which show the different accents and problems. For example, quite often the real estate market is defined as a set of agreements with real estate rights, as the interaction of supply and demand, the interaction of different real estate rights owners, etc. [1-3]. Of all these options, the most meaningful and accurate definition is the one given in the widely known work of J. Friedman and N. Ordway [4]: the real estate market is a set of mechanisms through which property rights and related interests are transferred, prices are set and space is allocated between different competing land use options. However, the regional real estate market has its own peculiarities that should be separately analyzed and investigated separately.

The purpose of the article is to identify the economic and financial elements, features and function of the regional real estate market.

The research results. Of course, the regional real estate market is a set of organizational and economic relations, a means of land redistribution, buildings, structures and other property between owners and users economic methods based on competitive demand and supply in the territory of the region (region) [5]. It provides through the mechanism of state regulation: transfer of the real estate rights from one person to another; setting equilibrium prices for the real estate in regions 
and localities; the relationship between the owners and buyers based on economic motivation and interests; the division of space between competing land use options and market actors.

The basis of the regional real estate market is existing land and newly created reconstructed and expanded enterprises, buildings and structures for various purposes, as well as money or financial capital. Lack of investment hinders technological modernization of enterprises and revival of domestic production of goods, which in turn narrows the country's investment opportunities. Incomplete investment activities are partially owned by the participants of this process until the investor accepts and pays for the completed works and services. In case of refusal of the client from further investment of the project, he/she is obliged to compensate the costs to other participants, unless otherwise stipulated in the contract.

The regional real estate market, as a self-regulatory legal environment, consists of seven basic elements, including financial: demand, supply, price, management, marketing, and infrastructure and business procedures.

Demand in the regional real estate market is the number of land plots, property complexes and the rights there to that buyer are prepared to purchase at complex prices over a period. All things being equal, the demand for real estate in the region changes inversely with the price. The demand for the real estate, such as land, is being formed under the influence of numerous factors - economic, social, demographic, natural and climatic.

The offer on the regional real estate market is the amount of land and other real estate (square meters, cubic meters, hundreds of hectares, apartments, etc.) that the owners are ready to sell at fixed prices for a certain period. The supply of fixed objects, especially land, is inelastic.

The most important element and condition for the existence of any regional market, including real estate - information infrastructure, which must contain reliable information of three types: about the existing rules and regulations of the real estate market and their expected changes; the structure of supply and demand for different objects; about the level and dynamics of prices of real estate objects by districts, microdistricts and other market segments. databases.

In practice, they use information systems developed by each company for their own use and regional corporate

Since real estate involves different combinations of legal rights and interests, in some cases the market may be leased, in others - mortgage obligations, in the third - an object of full ownership, free from any requirements. Multifunctional land use is further complicating the real estate market.

The regional real estate market has a great impact on all aspects of people's lives and activities, performing a number of general and special functions [5].

One of the main functions of market is to establish equilibrium prices at which solvent demand matches the volume of supply. At prices below equilibrium, there is excess demand, and at prices above equilibrium - excess supply. The price focuses on a large amount of information on the saturation of the regional market, customer preferences, construction costs, economic and social policies of the state in the area, such as housing, etc.

The regulatory function is that the market, autonomously functioning, according to A. Smith's definition, "invisibly hand" redistributes resources by business sector and directs its participants to a goal that is not at all intended to form an effective structure of the economy and satisfy the public interest [6]. In today's world, the shortcomings of market regulation are increasingly being offset by the public administration and the national economy, especially in the areas of nature protection, competition protection, income redistribution, creation of legal business environment, solving social problems, etc.

The commercial function is to realize the value and consumer value of the real estate and to make a return on invested capital.

The function of sanitation is to clean the economy from uncompetitive and weak market participants, inefficient bankruptcy. The market mechanism points people to the search directions, but does not give them any guarantees as to the final financial results. It recognizes only publicly needed real estate investments, because only the buyer pays them. Therefore, freeing the market from inefficient business owners and other real estate leads to increased sustainability and economic growth.

The information function is a unique market-based way of collecting and disseminating generic objective information promptly, allowing sellers and buyers of real estate to freely with the knowledge of the case, make decisions in their interests.

The intermediary function is expressed in the fact that the market acts as an aggregate mediator and meeting place for many independent, economically separated because of public division of labor of buyers and sellers, establishes a connection between them and provides an opportunity for alternative of partners. Act on the real estate market and professional intermediaries - realtors, appraisers, agents, brokers, insurers, mortgage lenders and other persons providing services to interested participants.

The incentive function ultimately acts as an economic incentive to profit from the productive use of scientific and technological progress in the creation and use of real estate. Competition economically compels and maintains high business activity and the search for new opportunities for effective capital management.

The investment function of the regional real estate market is an attractive way to save and increase the value of capital. It helps to translate the savings and savings of the population from the passive form of stocks into real productive capital, which brings income to the owner of the real estate. The real estate itself is a kind of insurance guarantee of investment risks.

The social function is manifested in the growth of labor activity of the whole population, the increase in the labor intensity of citizens seeking to become owners of apartments, land and other capital and prestigious objects. The real estate owners generally form the average social stratum of society. 
The redistribution function is the repeated redistribution in the market of enterprises, land, buildings and structures between different market entities, which ultimately leads to their transition to effective strategic investors, which ensures highperformance use of these objects.

Unlike other types on the regional real estate market, in addition to the specifics of the goods on it, there are a number of common features that must be taken into account when conducting transactions on it [5]: localization of the market, since its goods are immovable, unique, and their value is largely dependent on the external environment; open information about the situation on the regional real estate market is incomplete and not always reliable, since real estate transactions are often exclusive (exceptional) and confidential; demand is determined not only and not so much by the consumer qualities of the objects themselves, but mainly by their location; low elasticity of supply, because for a number of reasons it is impossible to build many new apartments at once, the buildings and structures themselves are durable and the earth is eternal; goods - real estate objects can be burdened with the morale of third parties (easements, etc.) in different combinations; relatively high degree of state regulation of the market by legislative norms and zoning: goods in the real estate market are not only a means of meeting the needs of buyers, but also the object of their investment activity; relatively smaller number of market participants and the number of operations performed on it; large variability in demand by region, district and neighborhood.

Therefore, in Fig. 1 presents the considered elements, features and functions of the regional real estate market.

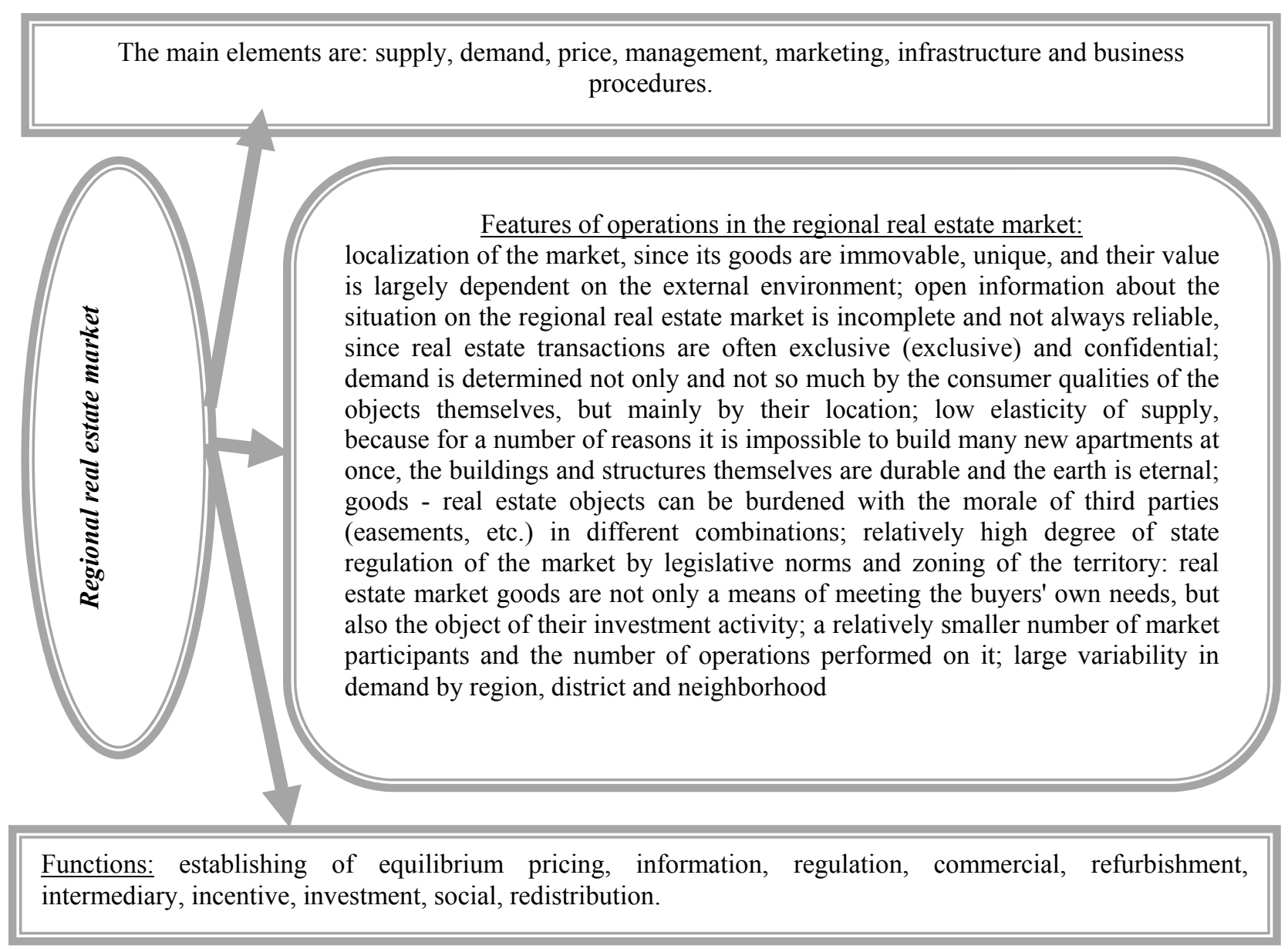

Figure 1 - Elements, features and functions of the regional real estate market

Conclusions. According to the results of the research were defined: economic and financial elements (demand, supply, price, management, marketing, infrastructure and business procedures), features (market localization, real estate transactions are often exclusive (exceptional) and confidential, demand is determined by their location); low elasticity of supply, comparatively high degree of market state regulation by legislative norms and zoning, real estate market goods are the object of their investment activity, relative to me and the number of market participants and the number of operations performed on it, the great variability of demand in regions, districts and districts) and the function of the regional real estate market (establishing equilibrium prices, information, regulation, commercial, sanitation, intermediary, stimulating, investment, social, redistribution).

\section{References.}

1. Asaul, A. M. Bryzhan', I. A. and Chevhanova, V. Ya., (2004), Ekonomika nerukhomosti: pidruchnyk [Real Estate Economics: Textbook], Libra, Kyiv, Ukraine

2. Zavora, T. (2006), "Real estate market and features of its functioning", Ekonomist, vol. 10, pp. 40-43

3. Mann, R.V. (2011), "Features of diagnosing the state and prospects of the real estate market", Ekonomika ta 
derzhava, vol. 9, pp. 15-17.

4. Friedman J., and Ordway N. (1995) Analysis and evaluation of real estate income. Case, Moscow, Russia.

5. Short course of lectures on the discipline "Real Estate Economics"(2019), available at: http: https://studme.com.ua/1612081514154/ekonomika/ekonomika nedvizhimosti.htm (Accessed 3 October 2019)

6. Smith A.(2007) Research on the nature and causes of the wealth of peoples, Eksmo, Moscow, Russia.

\section{Список літератури.}

1. Асаул А.М. Ринок нерухомості: навч. посіб. / А.М. Асаул, В.І. Павлов, І.І. Пилипенко, та ін. К., 2004. С. 17

2. Завора Т. Ринок нерухомості та особливості його функціонування / Т. Завора // Економіст. 2006. № 10. С. 40-43.

3. Манн Р.В. Особливості діагностування стану і перспектив розвитку ринку нерухомості / Р.В. Манн // Економіка та держава: наук.-практ. журнал. 2011. № 9. С. 15-17

4. Фрідман Дж., Ордуей Н. Аналіз та оцінка приносить дохід нерухомості. М.: Справа, 1995. С. 55.

5. Короткий курс лекцій 3 дисципліни «Економіка нерухомості». URL: https://studme.com.ua/1612081514154/ekonomika/ekonomika_nedvizhimosti.htm

6. Смит А. Исследование о природе и причинах богатства народов. М.: Эксмо, 2007. 960 с. 